\title{
Old Polish warrior's path - psychophysical and martial preparation of a young nobleman in modern Poland
}

\author{
Jakub POKOJSKI* \\ Idokan Poland Association in Rzeszów (Poland)
}

8th IMACSSS International Conference Abstracts, Viseu (Portugal), October 10-12, 2019

Type: Oral communication

\begin{abstract}
The article attempts to outline the path a young nobleman underwent in the 16-17th century Poland in order to achieve prowess in battle martial arts. It presents patterns and ways of training the nobleman was subjected to from an early age, the process of a future warrior's mental and physical preparation. Furthermore, it describes various types of body exercises and trainings with many weapon types. A fundamental novelty is presentation of the training methodology. Its over four centuries of age notwithstanding it has basically been valid until nowadays and encompasses such features as diet or exercise intensity. Eventually this article presents the individual stages of said training, closely related to warrior's age and psychophysical development. Material for the study was obtained thanks to the textual analysis, both from the era (16 to 17th century sources) and from the limited literature on the topics (monographs, magazine articles, periodicals, the Internet) addressing the subject. The result depicts arduous, however consistent and sensible old Polish training system. After many years of wisely carried out exercises an effective, skilled warrior was produced, furnished with high fighting skills and morale, ready to fight his country enemies. At the same time whilst getting old such a warrior could train the next generations of Homeland's knights-defenders. The objective of the article is to draw attention to the subject of Polish warriors, their training and martial arts, hitherto unmentioned in English literature and to encourage further research in this field.
\end{abstract}

Keywords: Martial arts; Polish martial arts; Polish sabre fencing; palcaty; training methodology; short stick fighting.

\section{Introduction}

The old Polish way of the warrior is an area almost unexplored to date (Sawicki 2004, Pokojski 2019). It was extremely far-reaching for the defense of Poland in the 16-18th centuries and for the development of native Polish martial art alongside with its methodological approach to warrior training. This training combined very strongly aspects of both physical and spiritual development. There are previous studies focused on individual historical figures but there has been no synthetic approach to the process of training a warrior in old Poland.

\section{Objectives}

This study focuses on showing the multifaceted process of training and education that warriors underwent from early childhood to adulthood as well as the methodology of the training itself. For the purposes of scientific research, few source materials from the period were examined alongside with literature on the subject, mainly in Polish (see references section).

\section{Methodology}

A thorough analysis and meta-analysis of available scarce sources from the era and few scientific papers on the subject was performed. The sources were subjected to an in-depth internal 
(hermeneutics) and external (erudite method) criticism. During the exegesis of the available textual material philological, comparative, progressive and ex silentio arguments were also used.

\section{Results}

Based on the analysis of the collected data, it should be stated that the training process of an Old Polish warrior was extremely arduous but comprehensive and ensuring proper psychophysical development. Thanks to the appropriate training methodology, proper nutrition, hygiene and diet, a Polish nobleman - a knight-warrior - coming of age was ready to take on the hardships he had to face during numerous wars in defense of faith and homeland. The conducted research shows that the old Polish way of the warrior, thanks to well thought-out training, provided healthy and strong warriors who also remained fit at an advanced age and were able to pass their knowledge and skills to future generations.

\section{Discussion}

The results obtained from this study can be juxtaposed with the conclusions of the work on the spiritual and physical development of warriors in other countries or cultural circles, such as Japan, Korea or China or Western European countries such as Spain, Portugal, France or Italy. Showing the previously neglected subject of Polish martial arts and the training process itself may become the beginning of a scientific discussion on the place of Polish martial arts in the global family of martial arts and comparative studies themselves within this family, with a multifaceted, multidisciplinary character. The very beginning of in-depth work on the subject will allow a fuller description of the cultural and historical wealth of Polish martial art of the Old polish period.

\section{Conclusion}

With this work a coherent picture of the training process of former Polish warriors has been obtained, systemically consistent and full, definitely tailored to the needs of the times in which it existed. What is more, the presented training methodology, despite being 400 years old, seems to meet today's requirements of healthy, modern training as well. Furthermore, the training of women warriors, unusual for the era, could also be confirmed. It was also shown the important role of teachers, masters in the educational and training process. They were regarded not only as trainers but also life teachers, guides on the path of young warriors' development

\section{References}

Borysiuk, Z. (2005). Historyczne przeobrażenie szabli jako broni siecznej. Ido - Ruch dla Kultury / Movement for Culture, 5, 9-15.

Brzeziński, R. (1987). The Polish Armies 1569-1696 (vol 1). London: Bloomsury Publishing.

Cynarski, W. J. (2012). A Christian and the martial arts path. Ido Movement for Culture. Journal of Martial Arts Anthropology, 16(2), 1-7. doi: 10.14589/ido.16.2.1

Cynarski, W. J. (2019). Martial Arts \& Combat Sports: Towards the General Theory of Fighting Arts. Gdańsk: Wydawnictwo Naukowe Katedra.

Cynarski, W. J., \& Litwiniuk, A. (2000). Metody przygotowani psychicznego w sztukach walki. IdoRuch dla Kultury / Movement for Culture, 1, 121-124.

Czajkowski, Z. (2007). Szermierka w dawnej Polsce. Ido - Ruch dla Kultury / Movement for Culture, 7, 55-64.

Górnicki, Ł. (1566). Dworzanin polski. Warszawa: Maciej Wirzbięta.

Łaski, S. (1599). Spraw i postępków rycerskich i przewagi opisanie krótkie. Lwów: M. Bernat.

Maroteaux, R. J. (2011). Special sabre polonais \& japonais. Aiki Goshin Do Kaishi, (55), 12-22. Avignon.

Maroteaux, R. J. (2019). Special sabre polonais. Aiki Goshin Do Kaishi, (77), 23-27.

Marsden, R. (2015). The polish saber. Cambridge: Tyrant Industries.

Paprocki, B. (1584). Herby rycerstwa polskiego. Kraków: Maciej Garwolczyk.

Petrycy, S. (1605). Polityki Arystelesowej to jest rzq̨du rzeczypospolitej z dokładem ksiąg ośmioro, część wtóra. Kraków: S. Kempini. 
Pokojski, K. (2019). Sarmaci najczystszym narodem chrześcijańskiej Europy - brud w XVI-XVII wiecznej Europie. Retrieved from http://www.kresy.pl/kresopedia,historia,rzeczpospolita?zobacz\%2Fsarmaci-najczystszymnarodem-chrzescijanskiej-europy-brud-w-xvi-xvii-wiecznej-europie

Pokojski, K. (2019). Szkolenie rycerskie jako istotny element wychowania młodego szlachcica w XVIXVIII wieku. Retrieved from http://szablaipiorem.pl/szkolenie-rycerskie-jako-istotnyelement-wychowania-modego-szlachcica-w-xvi-xvii-wieku

Pokojski, K. (2015). Tczew 1627. Warszawa: Erica.

Rej, M. (1567). Zwyerciadło albo kstałt w którym każdy stan snadnie się może swym sprawom iako we źwierciadle przypatrzyć. Kraków: M. Wirzbięta.

Sawicki, Z. (2014). Influence of the Polish martial art onto European armies in the 18th and 19th centuries. Ido Movement for Culture. Journal of Martial Arts Anthtopology, 14(4), 3-13. doi: 10.14589/ido.14.4.2

Sawicki, Z. (2008). Michała Starzewskiego traktat „O szermierstwie” $w$ interpretacji Zbigniewa Sawickiego. Zawiercie: Wydawnictwo Signum Polonicum.

Sawicki, Z. (2005). Palcaty. Podręcznik dla początkujących. Zawiercie: Wydawnictwo Signum Polonicum.

Sawicki, Z. (2019). Palcaty Staropolska szermierka na kije (Studium historyczne z dziejów kultury fizycznej). Author's collection materials from doctoral dissertation.

Sawicki, Z. (2011). PolishMartialArts - Signum Polonicum: Historical background and the main plots of the system. Ido Movement for Culture. Journal of Martial Arts Anthtopology, 11(2), 38-46.

Sawicki, Z. (2012). Traktat szermierczy o sztuce walki polskq szablq husarska część druga. Zawiercie: Wydawnictwo Napoleon V.

Sawicki, Z. (2004). Traktat szermierczy o sztuce walki szabla husarska. Podstawy. Zawiercie: Wydawnictwo Signum Polonicum.

Starowolski, Sz. (1631). Sarmatiae Bellatores, Koln: H. Kritius.

Testament Stanisława Żółkiewskiego. (1606). In A. Krasiński (Ed.). (1845). Biblioteka warszawska (Vol. 2, pp. 303-311). Warszawa: W Drunkarni Stanislawa Strabskiege. 